"Reconceptualizing and modeling sustainable consumption behavior: A synthesis of qualitative evidence from online education industry"

\begin{tabular}{|c|c|}
\hline AUTHORS & $\begin{array}{l}\text { Songyu Jiang } \\
\text { Ruihui } \mathrm{Pu} \text { (iD }\end{array}$ \\
\hline ARTICLE INFO & $\begin{array}{l}\text { Songyu Jiang and Ruihui Pu (2021). Reconceptualizing and modeling } \\
\text { sustainable consumption behavior: A synthesis of qualitative evidence from } \\
\text { online education industry. Innovative Marketing , 17(3), 144-156. } \\
\text { doi:10.21511/im.17(3).2021.12 }\end{array}$ \\
\hline DOI & http://dx.doi.org/10.21511/im.17(3).2021.12 \\
\hline RELEASED ON & Monday, 20 September 2021 \\
\hline RECEIVED ON & Friday, 30 July 2021 \\
\hline \multirow[t]{2}{*}{ ACCEPTED ON } & Monday, 13 September 2021 \\
\hline & $(\mathrm{sc}) \overline{\mathrm{EY}}$ \\
\hline LICENSE & $\begin{array}{l}\text { This work is licensed under a Creative Commons Attribution } 4.0 \text { International } \\
\text { License }\end{array}$ \\
\hline JOURNAL & "Innovative Marketing " \\
\hline ISSN PRINT & $1814-2427$ \\
\hline ISSN ONLINE & $1816-6326$ \\
\hline PUBLISHER & LLC "Consulting Publishing Company "Business Perspectives" \\
\hline FOUNDER & LLC "Consulting Publishing Company "Business Perspectives" \\
\hline
\end{tabular}

NUMBER OF REFERENCES

90

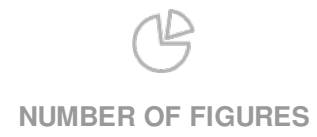

1
NUMBER OF TABLES

2

(C) The author(s) 2021. This publication is an open access article. 


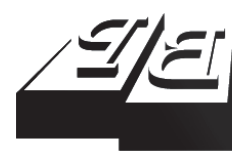

\section{BUSINESS PERSPECTIVES}

(O)

LLC "CPC "Business Perspectives"

Hryhorii Skovoroda lane, 10, Sumy, 40022, Ukraine

www.businessperspectives.org
Received on: $30^{\text {th }}$ of July, 2021 Accepted on: $13^{\text {th }}$ of September, 2021 Published on: $20^{\text {th }}$ of September, 2021

(C) Songyu Jiang, Ruihui Pu, 2021

Songyu Jiang, M.A., Rattanakosin International College of Creative Entrepreneurship, Rajamangala Univerity of Technology Rattanakosin, Thailand.

Ruihui Pu, Ph.D., Faculty of Economics, Srinakharinwirot University, Thailand. (Corresponding Author)
This is an Open Access article, distributed under the terms of the Creative Commons Attribution 4.0 International license, which permits unrestricted re-use, distribution, and reproduction in any medium, provided the original work is properly cited.

Conflict of interest statement: Author(s) reported no conflict of interest
Songyu Jiang (Thailand), Ruihui Pu (Thailand)

\section{RECONCEPTUALIZING}

AND MODELING SUSTAINABLE CONSUMPTION BEHAVIOR:

\section{A SYNTHESIS OF QUALITATIVE EVIDENCE FROM ONLINE EDUCATION INDUSTRY}

\begin{abstract}
In recent years, the concept of sustainable consumption behavior (SCB) is largely introduced and changed continuously to be discussed with industries such as energy sector, agriculture, transportation, sharing economy, and tourism. However, the study of sustainable consumption behavior in the online education industry (SCBOEI) remains a research gap. Thus, this paper aims to identify the significance of sustainable consumption behavior and theoretically conceptualize SCBOEI. This study employs content and text analysis to reconceptualize the major theories that contribute to the research of SCB. The findings in this study show that SCBOEI is contributed of great significance to promote sustainable development. In addition, this study introduces a model of SCBOEI, in which the consumer value theory, social exchange theory, and planned behavior theory are integrated. Additionally, this paper suggests that value, environmental attitude, identity, consumer engagement, and contextual factors (government behavior, market conditions, and environmental education) are highly important to extend the research on SCBOEI. In conclusion, this study strongly recommends that SCB research shall be directed to the online education industry. Furthermore, future studies shall emphasize the empirical effects of psychological factors, activity factors, and contextual factors for SCBOEI to find the correlation.
\end{abstract}

\section{Keywords}

JEL Classification

SCBOEI, Chongqing, identify, value, consumer, environmental education

M30, M31

\section{INTRODUCTION}

Human society is facing significant challenges, and various industries are looking for ways to reach sustainability (Pu \& Pathranarakul, 2019). Currently, developing countries are considering sustainable consumption behavior (SCB) more than developed countries (Lai, 2011). Some developing countries such as India (Cuevas et al., 2019), Brazil (Severo et al., 2017), Egypt (Shaban \& El-Bassiouny, 2015), and developed countries such as the United States (Cohen, 2005) and Germany (Vinz, 2009) focus on the development of SCB. In recent years, more and more studies begin to explore the SCB in China (Wang et al., 2014). Although many regions and industries value SCB, there are not enough research results on introducing SCB in Chongqing city.

The analysis on sustainable development in Chongqing mainly focuses on the tourism industry (Qizhia \& Xiang, 2012), energy industry (Sun \& Yang, 2019), agriculture (Zhang et al., 2018), the financial industry (Wang, 2017), and transportation industry (Wołek et al., 2021). Therefore, the sustainable development of the education industry is 
almost not involved. In recent decades, studies on SCB in Chongqing mainly include the SCB of rural residents (Sun \& Guo, 2018) and the SCB of water resources in the Three Gorges Dam Area (Rasul et al., 2021). At present, SCB studies mainly focus on durable products (Moragrega \& Ríos, 2021), online marketing (Hoa et al., 2021), and auto-industry (Mannacharaju et al., 2020). However, the education industry does not perform in the current academic stage. This study attempts to fill in this gap.

The contribution of the online education industry in Chongqing city aims to the development of Chongqing vocational training online education industry (Viberg et al., 2018), the supervision of Chongqing online education industry (Wu et al., 2021), and Chongqing online education industry under the background of COVID-19 (Xia \& Pei, 2021). Thus, this study concludes that the current results do not cover the sustainable development of the online education industry in Chongqing. Although the research results of online education are rich in 2010-2020, there is almost no combination of online education and SCB. The research results of the combination of education and sustainable development mainly aim to impact education on sustainable development or sustainable consumption. Higher education supplies the opportunities and challenges to sustainable consumption (Huyard, 2020). There are studies on online education from the perspective of education, yet ignoring SCB. The Chinese government issued abundant regulations to support the online education industry's development, protect the online education intellectual property, and supply high-quality online education resources (Xia \& Pei, 2021).

This paper analyzes the related works of literature to identify the research gaps and explains the significance of SCBOEI. Furthermore, the study establishes the theoretical framework through gap analysis, then models and conceptualizes SCBOEI based on the existing theories and concepts that suggest that value, attitude, identity, engagement, and contextual factors are important for SCBOEI.

\section{LITERATURE REVIEW}

This study plans to integrate the theories of sustainable consumption behavior and use them in the online education industry. Table 1 shows the research theory foundation of SCB: theory of planned behavior (TPB), social exchange theory (SET), and value-belief-norm theory (VBN). These theories provide solid theoretical support for the development of this study. However, there are rare studies based on integrating these three theories in one study on SCB.

As shown in Table 1, it is already an indisputable fact that attitude affects behavior. Environmental attitude positively affects green product purchase behavior, and students' learning environmental knowledge in school is also conducive to promoting their sustainable consumption. The theory of social exchange believes that contextual factors play an essential role in sustainable consumption behavior. The communication of humans in society enables individuals to perceive the function of reciprocity, knowledge sharing, and market conditions provide opportunities for such reciprocity. When consumers feel the convenience of govern- ment efforts and policies on sustainable development, they tend to buy environmental protection products with government subsidy policies, such as new energy vehicles and shared space. With the support of VBN theory, the value and identity of consumers are the crucial factors to predict their sustainable consumption behavior. College students feel the function of shared space, and they will produce an identity of environmental protection belief and promote their environmental behavior. In conclusion, these three theories have made outstanding contributions to the research on sustainable consumption behavior. This study will combine the three theories' views on SCB, development of the online education industry, and model SCBOEI.

TPB is a psychological theory that explains human behavior decision-making, which can help to understand how people change their behavior patterns (Azjen \& Fishbein, 1980). TPB involves the internal psychological preparation of behavioral intention and the influence of interaction with the external environment, significantly improving interpretation and prediction of behavior (Alam et al., 2020). TPB is widely used in many behavioral 
Table 1. Theoretical basis of sustainable consumption behavior in 2010-2020

Source: Authors' elaboration.

\begin{tabular}{|c|c|}
\hline Theoretical basis of SCB & References \\
\hline \multirow{9}{*}{ Theory of planned behavior } & Connell and Kozar (2014) \\
\hline & Sealza and Sealza (2014) \\
\hline & Wang (2017) \\
\hline & Yang et al. (2018) \\
\hline & Bernardes et al. (2018) \\
\hline & Čapienè (2019) \\
\hline & Yamoah and Acquaye (2019) \\
\hline & Park and Lin (2020) \\
\hline & Alam et al. (2020) \\
\hline Social exchange theory (contextual factors of SCB) & Cheng et al. (2017) \\
\hline \multirow{2}{*}{ Value-belief-norm theory (value, identity, norm of SCB) } & Martin and Väistö (2016) \\
\hline & Aygün et al. (2019) \\
\hline
\end{tabular}

fields; it significantly improves the research explanatory and predictive power (Hadjichambis et al., 2015). Based on the TPB, this study holds that consumer attitudes will have an impact on SCB. The study on SCB supported by TPB has made remarkable achievements. Yang et al. (2018) used TPB to prove that the double 11 Shopping Festival atmosphere harms the sustainable consumption behavior of Chinese people. Huyard (2020) investigated representative consumers in the United States, Mexico, and Indonesia and explored consumers' trust in sustainable products and the certification information in the packaging and labeling products. Alam (2020) expands TPB, introduces and discusses adaptation, which is the first step in implementing the concept of sustainable consumption in education. Integrating sustainability and incorporating the concepts of sustainable knowledge and sustainable values into the existing models can make up for these shortcomings. Dong et al. (2018) take the TPB extension as the research framework to determine the factors that affect the sustainable food consumption behavior of Malaysians. This paper constructs a framework to explore sustainable consumption behavior based on the TPB, contributing to three variables of attitude, value, and contextual factors as an essential part of the conceptual framework.

Stern (2000) proposed value-belief-norm (VBN) theory and asserted VBN origin from the interaction among value, faith, and specification. Egocentric, altruistic, and ecological characteristics are the three essential values (Dietz et al., 2005). These values influence people's beliefs, guide individual specifications, and lead to the formation of environmental behavior (Martin \& Väistö, 2016). VBN tried to explain individual environmental behavior within the categories of environmental activism, policy support, private-sphere behavior, and environmental citizenship (Stern, 2000). VBN theory argues that the tendency of pro-environmental behavior is closely related to the activation of personal norms. The sense of moral responsibility or personal responsibility is related to the individual's self-expectation of sustainable consumption (Park \& Lin, 2020). Therefore, once consumers realize the importance of the environment and set up their environmental values, they will make specific changes in SCB (Dietz et al., 2005). Based on this, this study believes that value, identity, and attitude are the essential factors of behavior, so the contribution of VBN to this study is more an internal and psychological factor. Gong et al. (2020), based on this theory, explored the crucial factors of belief and norm between value and environmental protection behavior and developed the direct positive influence of contextual factors on environmental protection behavior.

SET focuses on the psychological research of individuals and thinks that the interaction between human beings is a process of mutual exchange (Chatterjee et al., 2021). Social exchange is a kind of voluntary activity that individuals got paid back. In addition, the concept of rights, authority, and fairness is introduced, which makes SET more widely applied. To make the methodology of SET more comprehensive, Cook and Emerson (1987) expound on the social constructs, social reforms, and institutionalization process of social exchange with a rigorous mathematical model 
and network analysis making excellent contributions to the development of SET. If there is no social attraction, there will be no social exchange process. However, there is no explicit obligation in social exchange, and there is no bargaining in the way of return (Wang et al., 2019). Then, there is a principle involved in the exchange: one side bestows favor on the other side. Although the benefactor has an average expectation for some possible return in the future, the exact nature is not clearly defined before the act of bestowing a favor (Chatterjee et al., 2021). In other words, the nature of the return is related to the maintenance of social exchange relationships.

Chatterjee et al. (2021) used SET to investigate and test a series of variables related to attitudes and SCB. Based on SET, Wang et al. (2019) established a conceptual model to explore the mobilization mechanism of customers' SCB in the environment of sharing economy. Pimdee (2020), based on Thailand's context, uses the SET to discuss the SCB of Thailand's tourism industry. SET allows realizing that SCB is fundamentally a kind of reciprocal behavior. The interests of this behavior are longtermed and expected. It is precisely origin from such interests that consumers are willing to change their consumption patterns from value, identity, and even contextual factors. The study used SET framework to provide a dynamic sustainable consumption by exploring the cooperation of consumers' nature, environment, and behavior. The previous theoretical model provides SET framework of sustainable consumption related to reciprocal determinism. Individual, environmental and behavioral factors form an interactive feedback cycle using qualitative case studies. Hsiao and Su (2021) find out the crucial factors that affect English teachers' learning motivation and integrate the United Nations Sustainable Development Goals (SDG) into their teaching.
Therefore, this study is based on SET to construct SET framework to explain SCB.

Online education will become a new path for the innovation and development of higher education in the era of globalization and digitization (Zhang \& Li, 2020). Online education is a kind of "shadow education" attached to school education, which can find and fill the gaps in the traditional school education system (Leow et al., 2021).

SCB is different from ordinary consumption behavior, which is pursuing to meet basic needs and create a better life considering environmental protection, social equity, and other contradictory issues. At the same time, it also pays attention to the next generation's life (Fesenfeld et al., 2021). SCB gradually attract the attention of the whole world (Marzouk \& Mahrous, 2020). People must participate in sustainable development for the current social development (Pu \& Pathranarakul, 2019). Although there are many studies on SCB, the definition of SCB does not reach a consensus (Marzouk \& Mahrous, 2020). Table 2 shows a different understanding of SCB.

The definition of SCBOEI is not a consensus because the exploration of SCBOEI in academic work is too rare. However, from the definition of the online education industry, SCB is a voluntary behavior of consumers, recognizing the impact of the environment and society in the consumption process, and supporting sustainable development (Wang et al., 2014). Therefore, this study defines SCBOEI as the environmental and social impact on consumers who are aware of consuming the online education industry. Through the online education platform, products can support sustainable development. SCB is an environmental protection product to improve consumption, reduce natural resources, and realize fu-

Table 2. Sustainable consumption behavior in different perspectives

Source: Authors' elaboration.

\begin{tabular}{l|c}
\hline \multicolumn{1}{c}{ Perspectives of SCB } & References \\
\hline Consumerism/traditional consumption. & Luchs and Mooradian (2012) \\
Shared social welfare, and promoted sustainable social development. & Sigala (2014) \\
Meeting the needs without harming people's interests in the future. & Wang et al. (2014) \\
SCB will be affected by value, attitude, and contextual factors. & Taufique et al. (2017) \\
Consumption mode of resource concern and environmental protection. & Spangenberg and Lorek (2019) \\
Buying environmentally-friendly products or boycotting the products from irresponsible companies. & Nguyen et al. (2020) \\
A social-level problem involving a wide range of areas. & Concari et al. (2020) \\
Encouraging environmental preservation by engaging in behavior that would reduce resources and & Dermody et al. (2021) \\
energy. &
\end{tabular}


ture aspirations and meet current needs by changing lifestyle (Spangenberg \& Lorek, 2019).

This study recognizes that online education products are more environmentally friendly than traditional education products and more conducive to different groups to acquire knowledge and change the traditional education model to achieve educational equity further and promote sustainable development. SCB includes two key aspects: minimum waste of environmental protection and voluntary behavior of maintaining product life cycle (Wang et al., 2014). Therefore, based on the online education industry, SCB is a kind of behavior that tries to reduce waste and further promote online education products to the whole society. This kind of behavior is beneficial to both production and consumption. SCB refers to personal behavior and a concept of behavior, which encourages the consumption of sustainable products in the process of economic development (Concari et al., 2020). Therefore, the definition of SCBOEI in this study is the spontaneous and positive development of the online education industry. It meets its learning and education needs and pays attention to the sustainable development of society. Through the consumption of the online education industry, it consciously pays attention to the crucial issues of sustainable development such as education equity, environmental issues, and harmonious economic development. It can also take the next generation's education into its responsibility.

The variations in individuals' personal, social, and cultural experiences generate value differences and the stability of value and value systems (Sun \& Yang, 2019). However, applying this theory in predicting SCB is quite limited (Sharma \& Jha, 2017). This study explains value from five dimensions: society, emotion, function, psychology, and environment. Social value is a kind of achievement that individuals feel when they are integrating into society. It is a sign of whether they can cooperate with a group, emphasizing the importance of its contribution to society (Ratten, 2020). Social value reflects a kind of social status and social contribution (Tian et al., 2011). Emotional value is the emotional belonging of a person to an activity, which can arouse people's enthusiasm in sustainable consumption behavior (Shan et al., 2021). Functional value is the consideration of product practicability in the process of sustainable consumption, and it is the most basic and original power when people buy products (King, 2016). Some aspects reflect the functional value that consumers can readily perceive, such as price, decoration, design, and so on (Lee et al., 2015). When people consume sustainable products, they focus on the cost performance and function of the products. The functional value can measure the original motivation of people when they buy sustainable products (Lin \& Huang, 2012). Similarly, the online education industry in Chongqing can bring more convenience to consumers regarding price, quality, and efficiency. The characteristics of online education are different from traditional face-to-face education, which changes the concept of time and space in traditional education.

Environmental value (ENV) is an individual's willingness to take the initiative to pay attention to environmental issues, which will encourage people to promote sustainable development by changing themselves, others, or the way of donation (Haupt \& Hellweg, 2019). ENV means that a person shows environmentalism in his actions, thoughts, and even words (Haupt \& Hellweg, 2019). EVN emphasizes that consumers should pay attention to the environmental commitment and responsibility of products in the process of consumption, try their best to pursue minimal environmental harm, and make circular consumption and sustainable consumption to build a sustainable society (Ratten, 2020). Psychological value makes consumers find a psychological balance in sustainable consumption. Moreover, consumers can feel satisfaction through this balance (Lin \& Huang, 2012).

Attitude usually is an internal psychological factor to explain sustainable consumption; it is also one of the critical topics in sustainable consumption research, tourism, education, economy, and other fields (Jugert et al., 2016). Environmental attitude includes two aspects: environmental concern and environmental efficacy (Clayton et al., 2017). This study would like to introduce the environmental concern and environmental efficacy from the perspective of SCBOEI.

Environmental concern is a comprehensive concept, which contains emotions, knowledge, attitudes, values, and behaviors (Cruz \& Manata, 2020). Environmental concern is an attitude of active cognition and evaluation of environmental problems. Indeed, consumers' environmental concern 
is closely related to their environmental perception in life, environmental knowledge, and environmental value (Cruz \& Manata, 2020). The advantage of environmental concern lies in encouraging consumers to choose sustainable consumption mode and enhance consumers' environmental awareness and social responsibility, which is different from the standard consumption mode. It is also one of the goals for environmental concern (Dermody et al., 2021). In sustainable development, environmental efficacy is a sensitivity of a person to environmental problems. This sensitivity will promote individuals to care about environmental problems, which is an attitude towards the environment (Jugert et al., 2016). Environmental efficacy can affect personal behavior and improve the living environment (Dermody et al., 2021). Improving environmental efficacy means promoting environmental behavior, and environmental efficacy is one of the critical factors affecting sustainable consumption behavior. Basil et al. (2020) evident that the improvement of environmental efficacy can promote environmental protection behavior (Basil et al., 2020). Thus, environmental efficacy is an essential factor in the sustainable consumption research of the online education industry in Chongqing city.

Environmental attitude and environmental behavior are two closely related concepts, so environmental attitude seems to affect the sustainable consumption behavior of consumers (Concari et al., 2020). The environmental attitude should be an essential factor in the study of sustainable consumption (Wang et al., 2014). Environmental attitude and environmental behavior play positive roles in the process of green product consumption (Lin \& Niu, 2018). If a person has a positive environmental attitude, he will be willing to transfer his traditional consumption pattern to sustainable consumption behavior (Lee et al., 2015). The consumers' environmental attitudes are often determining the adoption of SCB (Elhoushy \& Lanzini, 2021).

Nigbur et al. (2010) pay attention to the relationship between identity and SCB. Identity is divided into three aspects: self-identity (Nigbur et al., 2010), social identity (Duroy, 2011), and place identity (Foroudi et al., 2020). Self-identity plays a vital role in explaining why consumers choose sustainability, which refers to combining a series of roles completed by a person. In turn, it persuades a person to take continuous actions to recognize self-concept
(Confente et al., 2020). It is a label for SCB and identification to prove that they love the environment and pay attention to social development (Foroudi et al., 2020). Self-identity is the benefit to distinguish the social groups that different individuals integrate into and the difference in their values, beliefs, and behaviors (Confente et al., 2020).

Social identity is a sense of belonging in society, which means identification with the group to which an individual belongs (Tajfel, 1979). Social identity theory emphasizes interaction between an individual and society. Moreover, it is the shaping of self-concept and the relationship between an individual and society, providing some suggestions for this interaction (Hogg, 2020). The literature on place identity focuses on the attributes of a particular location and suggests that it can affect actions to protect local ecosystems from development threats (Confente et al., 2020). Place identity is about where an individual belongs; it suggests that people in different places have a different identity. The different physical environments will shape the different sense of identity and basic cognition of human society (Antonsich, 2010).

Engagement is a transitional form of social and interactive behavior produced by developing a relevant engagement process in a certain period (Gatautis et al., 2021). CE usually refers to that consumers integrate (Antonsich, 2010) into organizations, products, and brands and make emotional and physical contributions to the consumption they are concerned about (Piligrimiene et al., 2020). CE frequently involves three main dimensions: cognitive, emotional, and behavioral engagement (Javornik \& Mandelli, 2013). Cognitive engagement is a kind of emotion that refers to external factors, which is in the field of education and psychology. It is a kind of psychological investment in academic activities and persistence in learning tasks (Lo \& Hew, 2020). Cognitive engagement represents consumers' understanding of sustainable consumption behavior, which attempts to change the social environment and promote sustainable social development through the behavior (Piligrimienè et al., 2020). As an essential aspect of consumer engagement, emotional engagement is gradually concerned in consumer behavior research (Özhan \& Kocadere, 2020). Emotional engagement is a sense of pride and achievement in solving the problems faced by sustainable social development. 
Behavioral engagement is an essential psychological concept (Piligrimiene et al., 2020). It is the actual behavior of consumers in the process of sustainable consumption, including cultivating sustainable awareness, understanding sustainable knowledge, purchasing sustainable products, and promoting sustainable development (Piligrimienè et al., 2020).

Contextual factors will have positive or negative effects on SCB (Kostadinova, 2016). The current study examines the influence of government behavior, market environment, and environmental education on SCB in different fields (which mainly involve energy sector and food industry). Government acts as a management procedure specified by the government in sustainable consumption action, including organization construction, policy and decree promulgation, and incentive measures to promote consumers to choose sustainable consumption (Cejudo \& Michel, 2017). Government action is an essential external factor to promote sustainable development. It makes reasonable arrangements in social rules, encourages individuals to participate in sustainable consumption actively, and lets consumers take the responsibility of sustainable development in a certain way (Cejudo \& Michel, 2017). Market condition is a broad concept, which is the conditions of sustainable consumption in the market. Specifically, when consumers purchase, use, and dispose sustain- able commodities, the market can bring conveniences to consumers, and these conveniences can promote consumers' sustainable consumption behavior (Baharumshah et al., 2017). Environment education introduces environmental knowledge to students and their parents in social development (Agha et al., 2018). EE refers to consumers' understanding of environmental knowledge in the process of sustainable consumption, including their learning and understanding of sustainable development. To some extent, $\mathrm{EE}$ is a kind of ability to solve the problem of sustainable development. If the EE performance of consumers is more outstanding than other traditional consumers, they will usually pay more attention to environmental protection and environmental improvement and be inclined towards SCB (Agha et al., 2018).

\section{AIM}

Based on the introduction of the theoretical basis and the explanation of related concepts, this study aims to model and conceptualize sustainable consumption behavior and put forward a conceptual framework of SCBOEI. Figure 1 explores environmental attitude, consumer engagement, and contextual factors from the theory of planned behavior; value, attitude, identity, and contextu-

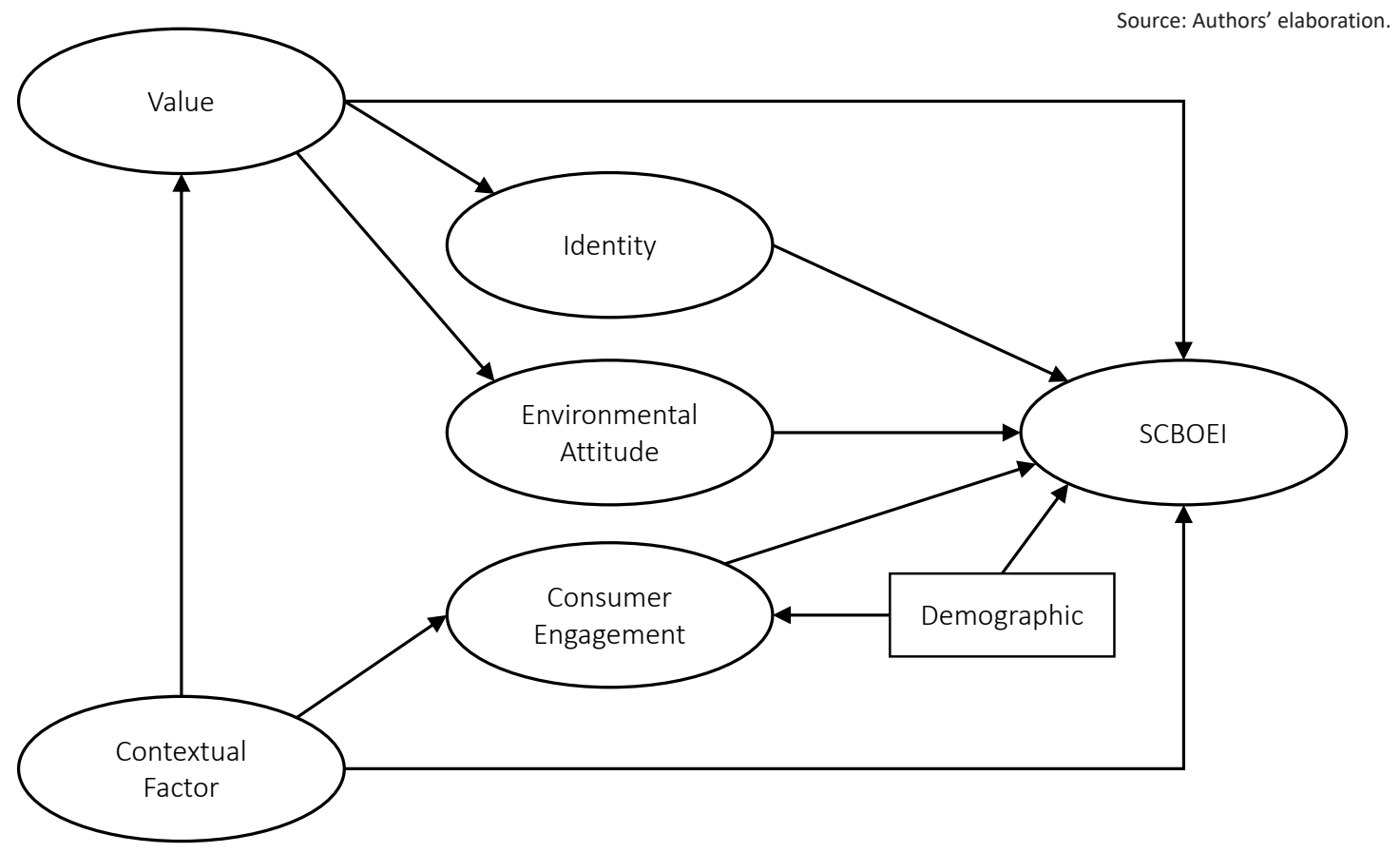

Figure 1. Conceptualized SCBOEI framework 
al factors from the value-belief-norm theory; and identity, engagement, and contextual factors from the social exchange theory. Then, based on the understanding of the online education industry, this paper defines and explains SCBOEI. Indeed, this study also introduces the sub-factors. Social value, environmental value, functional value, emotional value, psychological value, self-identity, social identity, place identity, environmental concerns and environmental efficacy, cognitive engagement, emotional engagement, and behavioral engagement can explain consumer engagement. There are several dimensions in contextual factors, such as government action, market condition, and environmental education. The construction introduces the sub-facto.

\section{DISCUSSION}

This study has its intention to introduce and contribute the breakthroughs and models generated from existing theory and creates a model for sustainable consumption behavior in the online education in- dustry. This study suggests that value, identity, environmental attitude, consumer engagement, and contextual factors are salient to explain SCBOEI. It shows that environmental attitude, identity, and consumer engagement are the intermediate bridges for the study of SCBOEI. However, the findings in this study have limitations of generalizing the empirical evidence to explain the entire education sector, because this study aims to reconceptualize the research of the online education industry based on existing theory. Therefore, future research shall analyze empirical data on this issue.

Although the study is to model SCBOEI, this paper begins to pay attention to online education as a new emerging industry for sustainable development. This study tries to break through the traditional research field of sustainable consumption behavior to capture new clues about promoting sustainable development. In the digital and knowledge economy era, there are sufficient reasons to pay attention to the online education industry and promote the online education industry to serve sustainable development.

\section{CONCLUSION}

The paper suggests that SCBOEI is conducive to promoting sustainable development. It is noted that one needs to pay attention to the sustainable consumption behavior of the education industry. The study defines SCBOEI and achieves innovations and breakthroughs in the theory. Moreover, this study comprehensively conceptualizes the value, identity, attitude, and contextual factors of SCBOEI, especially the vital role of market environment, government behavior, and environmental education for SCBOEI. In other words, these dimensions are essential for SCBOEI.

It can promote the sustainable development of the online education industry in Chongqing and give local marketing people, policymakers of education departments necessary recommendations; in addition, it provides suggestions for consumers of online education. This study helps to pay more attention to the consumer behavior of the online education industry and promote sustainable development, thus providing some theoretical support and pertinent suggestions for market planning or marketing personnel. Therefore, it promotes the sustainable development of the online education industry. In conclusion, this paper strongly recommends that SCB research shall be directed to the online education industry. Furthermore, future studies shall emphasize the empirical effects of psychological factors, activity factors, and contextual factors for SCBOEI.

\section{AUTHOR CONTRIBUTIONS}

Conceptualization: Songyu Jiang.

Data curation: Ruihui Pu.

Formal analysis: Ruihui $\mathrm{Pu}$.

Methodology: Songyu Jiang, Ruihui Pu. 
Project administration: Ruihui $\mathrm{Pu}$.

Supervision: Ruihui $\mathrm{Pu}$.

Validation: Songyu Jiang, Ruihui $\mathrm{Pu}$.

Visualization: Songyu Jiang, Ruihui $\mathrm{Pu}$

Writing - original draft: Songyu Jiang.

Writing - review \& editing: Ruihui Pu.

\section{REFERENCES}

1. Agha, S., Mekkawy, W., IbanezEscriche, N., Lind, C., Kumar, J., Mandal, A., Benzie, J.A.H., \& Doeschl-Wilson, A. (2018). Breeding for robustness: investigating the genotype-byenvironment interaction and micro-environmental sensitivity of Genetically Improved Farmed Tilapia (Oreochromis niloticus). Animal genetics, 49(5), 421-427. https://doi.org/10.1111/age.12680

2. Alam, S. S., Ahmad, M., Ho, Y.-H., Omar, N. A., \& Lin, C.-Y. (2020). Applying an Extended Theory of Planned Behavior to Sustainable Food Consumption. Sustainability, 12(20), 8394. https:// doi.org/10.3390/su12208394

3. Antonsich, M. (2010). Meanings of place and aspects of the self: an interdisciplinary and empirical account. GeoJournal, 75(1), 119132. Retrieved from https://www. jstor.org/stable/41148388

4. Aygün, B., Şakar, E., Korkut, T., Sayyed, M. I., \& Karabulut, A. (2019). New high temperature resistant heavy concretes for fast neutron and gamma radiation shielding. Radiochimica Acta, 107(4), 359-367. https://doi. org/10.1515/ract-2018-3075

5. Azjen, I., \& Fishbein, M. (1980). Understanding attitudes and predicting social behavior. Englewood Cliffs, N.J.: PrenticeHall.

6. Baharumshah, A. Z., Soon, S.-V., \& Lau, E. (2017). Fiscal sustainability in an emerging market economy: When does public debt turn bad? Journal of Policy Modeling, 39(1), 99-113. https://doi.org/10.1016/j. jpolmod.2016.11.002

7. Basil, D. Z., Basil, M., Lavack, A. M., \& Deshpande, S. (2020). Toward developing an environmental efficacy construct. Journal of Social Marketing, 10(1), 1-17. https://doi.org/10.1108/ JSOCM-02-2019-0017

8. Bernardes, J. P., Ferreira, F., Marques, A. D., \& Nogueira, M. (2018). "Do as I say, not as I do"-a systematic literature review on the attitude-behaviour gap towards sustainable consumption of Generation Y. IOP Conference Series: Materials Science and Engineering, 459, 012089. Retrieved from https://iopscience. iop.org/article/10.1088/1757899X/459/1/012089

9. Čapienè, A. (2019). Theories, models and trends of sustainable consumption attitude-behaviour gap. Management Theory and Studies for Rural Business and Infrastructure Development, 41(3), 332-341. https://doi.org/10.15544/ mts.2019.27

10. Cejudo, G. M., \& Michel, C. L. (2017). Addressing fragmented government action: Coordination, coherence, and integration. Policy Sciences, 50(4), 745-767. https:// link.springer.com/article/10.1007/ s11077-017-9281-5

11. Chatterjee, A., Gerdes, M., Prinz, A., \& Martinez, S. (2021). Human Coaching Methodologies for Automatic Electronic Coaching (eCoaching) as Behavioral Interventions With Information and Communication Technology: Systematic Review. Journal of Medical Internet Research, 23(3), e23533. https://www.ncbi.nlm.nih. gov/pmc/articles/PMC8074867/

12. Cheng, H., Chen, C., Wu, S., Mirza, Z. A., \& Liu, Z. (2017). Emergy evaluation of cropping, poultry rearing, and fish raising systems in the drawdown zone of Three Gorges Reservoir of China.
Journal of Cleaner Production, 144, 559-571. http://dx.doi. org/10.1016/j.jclepro.2016.12.053

13. Clayton, S., Prévot, A. C., Germain, L., \& Saint-Jalme, M. (2017). Public support for biodiversity after a zoo visit: Environmental concern, conservation knowledge, and self-efficacy. Curator: The Museum Journal, 60(1), 87-100. https://doi. org/10.1111/cura.12188

14. Cohen, M. J. (2005). Sustainable consumption American style: nutrition education, active living and financial literacy. The International Journal of Sustainable Development \& World Ecology, 12(4), 407-418. http://dx.doi. org/10.1080/13504500509469650

15. Concari, A., Kok, G., \& Martens, P. (2020). A Systematic Literature Review of Concepts and Factors Related to Pro-Environmental Consumer Behaviour in Relation to Waste Management Through an Interdisciplinary Approach. Sustainability, 12(11), 4452. https://doi.org/10.3390/ su12114452

16. Confente, I., Scarpi, D., \& Russo, I. (2020). Marketing a new generation of bio-plastics products for a circular economy: The role of green self-identity, selfcongruity, and perceived value. Journal of Business Research, 112, 431-439. https://doi.org/10.1016/j. jbusres.2019.10.030

17. Connell, K. Y. H., \& Kozar, J. M. (2014). Environmentally sustainable clothing consumption: knowledge, attitudes, and behavior. In Roadmap to sustainable textiles and clothing (pp. 41-61). Springer.

18. Cook, K. S., \& Emerson, R. M. (1987). Social exchange theory. 
Beverly Hills, California: Sage Publications.

19. Cruz, S. M., \& Manata, B. (2020). Measurement of environmental concern: A review and analysis. Frontiers in Psychology, 11, 363. https://doi.org/10.3389/ fpsyg.2020.00363

20. Cuevas, S., Downs, S. M., GhoshJerath, S., Aafrin, \& Shankar, B. (2019). Analysing the policy space for the promotion of healthy, sustainable edible oil consumption in India. Public health nutrition, 22(18), 3435-3446. http://doi. org/10.1017/S1368980019001836

21. Dermody, J., Koenig-Lewis, N., Zhao, A. L., \& Hanmer-Lloyd, S. (2021). Critiquing a Utopian idea of Sustainable Consumption: A Post-Capitalism Perspective. Journal of Macromarketing. https://doi.org/10.1177\%2F0276146720979148

22. Dietz, T., Fitzgerald, A., \& Shwom R. (2005). Environmental values. Annual Review of Environment and Resources, 30(1), 335-372. https://doi.org/10.1146/annurev. energy.30.050504.144444

23. Dominici, G., \& Palumbo, F. (2013). How to build an e-learning product: Factors for student/ customer satisfaction. Business Horizons, 56(1), 87-96. https://doi. org/10.1016/j.bushor.2012.09.011

24. Dong, X., Li, H., Liu, S., Cai, C., \& Fan, X. (2018). How does material possession love influence sustainable consumption behavior towards the durable products? Journal of Cleaner Production, 198, 389-400. https://doi.org/10.1016/j. jclepro.2018.07.054

25. Duroy, Q. (2011). The path to a sustainable economy: sustainable consumption, social identity and ecological citizenship. International Journal of Green Economics, 5(1), 1-14. http://dx.doi.org/10.1504/ IJGE.2011.039725

26. Elhoushy, S., \& Lanzini, P. (2021). Factors affecting sustainable consumer behavior in the MENA region: A systematic review. Journal of International Consumer Marketing, 33(3), 256-279. https:// doi.org/10.1080/08961530.2020.1 781735

27. Fesenfeld, L. P., Sun, Y., Wicki, M., \& Bernauer, T. (2021). The role and limits of strategic framing for promoting sustainable consumption and policy. Global Environmental Change, 68, 102266. https://doi.org/10.1016/j.gloenvcha.2021.102266

28. Foroudi, M. M., Balmer, J. M., Chen, W., Foroudi, P., \& Patsala, P. (2020). Explicating place identity attitudes, place architecture attitudes, and identification triad theory. Journal of Business Research, 109, 321-336. https://doi. org/10.1016/j.jbusres.2019.12.010

29. Gatautis, R., Banytè, J., \& Vitkauskaite, E. (2021). Gamification and Consumer Engagement. Springer.

30. Gong, X., Zhang, J., Zhang, H., Cheng, M., Wang, F., \& Yu, N. (2020). Internet use encourages pro-environmental behavior: Evidence from China. Journal of Cleaner Production, 256, 120725. https://doi.org/10.1016/j. jclepro.2020.120725

31. Guan, J., \& Li, Q. (2014). The current situation, trend and experience of online education in China. China's E-education (8), 62-66.

32. Hadjichambis, A. C., ParaskevaHadjichambi, D., Ioannou, H., Georgiou, Y., \& Manoli, C. C. (2015). Integrating sustainable consumption into environmental education: A case study on environmental representations, decision making and intention to act. International Journal of Environmental and Science Education, 10(1), 67-86. Retrieved from http://www.ijese.net/ makale/148.html

33. Haupt, M., \& Hellweg, S. (2019). Measuring the environmental sustainability of a circular economy. Environmental and Sustainability Indicators, 1-2, 100005. https://doi.org/10.1016/j. indic.2019.100005

34. Hoa, N. T., Tuan, T. T., Tung, T., \& Huan, P. Q. (2021). Factors affecting online purchase behaviour in vietnam. Academy of Accounting and Financial Studies Journal, 25(4), 1-11. Retrieved from https://www.abacademies. org/articles/Factors-affectingonline-purchase-behaviour-invietnam-\%201528-2635-25-4-772. pdf

35. Hogg, M. A. (2020). Social identity theory. Stanford University Press.

36. Hsiao, P.-W., \& Su, C.-H. (2021). A Study on the Impact of STEAM Education for Sustainable Development Courses and Its Effects on Student Motivation and Learning. Sustainability, 13(7), 3772. https://doi.org/10.3390/ su13073772

37. Huyard, C. (2020). Sustainable food education: what food preparation competences are needed to support vegetable consumption? Environmental Education Research, 26(8), 11641176. https://doi.org/10.1080/1350 4622.2020.1779187

38. Javornik, A., \& Mandelli, A. (2013). Research categories in studying customer engagement. AM2013 Academy of Marketing Conference.

39. Jugert, P., Greenaway, K. H., Barth, M., Büchner, R., Eisentraut, S., \& Fritsche, I. (2016). Collective efficacy increases proenvironmental intentions through increasing self-efficacy. Journal of Environmental Psychology, 48, 12-23. https://doi.org/10.1016/j. jenvp.2016.08.003

40. King, L. O. (2016). Functional sustainability indicators. Ecological indicators, 66, 121131. https://doi.org/10.1016/j. ecolind.2016.01.027

41. Kostadinova, E. (2016). Sustainable consumer behavior: Literature overview. Economic Alternatives, 2, 224-234. https:// ideas.repec.org/a/nwe/eajour/ y2016i2p224-234.html

42. Lai, W.-H. (2011). Willingness-toengage in technology transfer in industry-university collaborations. Journal of Business Research, 64(11), 1218-1223. https://doi. org/10.1016/j.jbusres.2011.06.026

43. Lee, C. K., Levy, D. S., \& Yap, C. S. F. (2015). How does the theory 
of consumption values contribute to place identity and sustainable consumption? International Journal of Consumer Studies, 39(6), 597-607. https://doi.org/10.1111/ ijcs. 12231

44. Leow, L. P., Phua, L. K., \& Teh, S. Y. (2021). Extending the social influence factor: behavioural intention to increase the usage of information and communication technology-enhanced studentcentered teaching methods. Educational Technology Research and Development, 69(3), 18531879. Retrieved from https://eric. ed.gov/?id=EJ1302916

45. Lin, P.-C., \& Huang, Y.-H. (2012). The influence factors on choice behavior regarding green products based on the theory of consumption values. Journal of Cleaner Production, 22(1), 11-18. https://doi.org/10.1016/j. jclepro.2011.10.002

46. Lin, S. T., \& Niu, H. J. (2018). Green consumption: Environmental knowledge, environmental consciousness, social norms, and purchasing behavior. Business Strategy and the Environment, 27(8), 1679-1688. https://doi.org/10.1002/bse.2233

47. Lo, C. K., \& Hew, K. F. (2020). A comparison of flipped learning with gamification, traditional learning, and online independent study: the effects on students' mathematics achievement and cognitive engagement. Interactive Learning Environments, 28(4), 464-481. http://dx.doi.org/10.1080 /10494820.2018.1541910

48. Luchs, M. G., \& Mooradian, T. A. (2012). Sex, personality, and sustainable consumer behaviour: Elucidating the gender effect. Journal of Consumer Policy, 35(1), 127-144. http://doi.org/10.1007/ s10603-011-9179-0

49. Mannacharaju, M., Villalan, A. K., Shenbagam, B., Karmegam, P. M., Natarajan, P., Somasundaram, S., Arumugam, G., \& Ganesan, S. (2020). Towards sustainable system configuration for the treatment of fish processing wastewater using bioreactors. Environmental Science and
Pollution Research, 27(1), 353-365. https://doi.org/10.1007/s11356019-06909-x

50. Martin, D. M., \& Väistö, T. (2016) Reducing the attitude-behavior gap in sustainable consumption: A theoretical proposition and the American electric vehicle market. In Marketing in and for a Sustainable Society (pp. 193 213). Emerald Group Publishing Limited. https://doi.org/10.1108/ S1548-643520160000013016

51. Marzouk, O. A., \& Mahrous, A. A (2020). Sustainable consumption behavior of energy and waterefficient products in a resourceconstrained environment. Journal of Global Marketing, 33(5), 335353. https://doi.org/10.1080/08911 762.2019.1709005

52. Mehta, S., Saxena, T., \& Purohit, N. (2020). The new consumer behaviour paradigm amid COVID-19: Permanent or transient? Journal of Health Management, 22(2), 291-301. https://doi.org/10.1177\%2F0972063420940834

53. Moragrega, I., \& Ríos, J. L. (2021). Medicinal plants in the treatment of depression: Evidence from preclinical studies. Planta medica, 87(9), 656-685.

54. Nguyen, A. T., Parker, L., Brennan, L., \& Lockrey, S. (2020). A consumer definition of ecofriendly packaging. Journal of Cleaner Production, 252, 119792. https://doi.org/10.1016/j. jclepro.2019.119792

55. Nigbur, D., Lyons, E., \& Uzzell, D. (2010). Attitudes, norms, identity and environmental behaviour: Using an expanded theory of planned behaviour to predict participation in a kerbside recycling programme. British Journal of Social Psychology, 49(2), 259-284. https://doi. org/10.1348/014466609X449395

56. Özhan, Ş. Ç., \& Kocadere, S. A. (2020). The effects of flow, emotional engagement, and motivation on success in a gamified online learning environment. Journal of Educational Computing Research, 57(8), 2006-2031. https://doi.org /10.1177\%2F0735633118823159
57. Park, H. J., \& Lin, L. M. (2020). Exploring attitude-behavior gap in sustainable consumption: Comparison of recycled and upcycled fashion products. Journal of Business Research, 117, 623-628. https://doi.org/10.1016/j. jbusres.2018.08.025

58. Piligrimienè, Ž., Žukauskaité, A., Korzilius, H., Banytė, J., \& Dovaliené, A. (2020). Internal and external determinants of consumer engagement in sustainable consumption. Sustainability, 12(4), 1349. https:// doi.org/10.3390/su12041349

59. Pimdee, P. (2020). Antecedents of Thai student teacher sustainable consumption behavior. Heliyon, 6(8), e04676. http://dx.doi. org/10.1016/j.heliyon.2020.e04676

60. Pu, R., \& Pathranarakul, P. (2019). Sharing Economy as Innovative Paradigm Towards Sustainable Development: A Conceptual Review. Journal of Reviews on Global Economics, 8, 387-398. Retrieved from https://ideas.repec. org/a/lif/jrgelg/v8y2019p387-398. html

61. $\mathrm{Pu}, \mathrm{R} .$, Teresiene, D., Pieczulis, I., Kong, J., \& Yue, X.-G. (2021). The Interaction between Banking Sector and Financial Technology Companies: Qualitative Assessment - A Case of Lithuania. Risks, 9(1), 21. https://doi. org/10.3390/risks9010021

62. Qizhia, Y., \& Xiang, Y. (2012). The Research on the Contribution of Rural Tourism to Peasants' Income - Based on the empirical analysis of Chengdu. On Economic Problems, 9 .

63. Rasul, G., Neupane, N., Hussain, A., \& Pasakhala, B. (2021). Beyond hydropower: towards an integrated solution for water, energy and food security in South Asia. International Journal of Water Resources Development 37(3), 466-490. https://doi.org/10 1080/07900627.2019.1579705

64. Ratten, V. (2020). Coronavirus (covid-19) and social value co-creation. International Journal of Sociology and Social Policy. https://doi.org/10.1108/ IJSSP-06-2020-0237 
65. Razzaque, A. (2021). Artificial Intelligence and IT Governance: A Literature Review. In A.M.A. Musleh Al-Sartawi (Ed.), The Big Data-Driven Digital Economy: Artificial and Computational Intelligence (pp. 85-97). Cham: Springer. https://doi. org/10.1007/978-3-030-73057-4_7

66. Sealza, I. S., \& Sealza, L. P. (2014). Recovering from the effects of natural disaster: the case of urban Cagayan de Oro, Philippines. European Journal of Sustainable Development, 3(3), 103. https://doi. org/10.14207/ejsd.2014.v3n3p103

67. Severo, E. A., de Guimarães, J. C. F., Brito, L. M. P., \& Dellarmelin, M. L. (2017). Environmental sustainability and sustainable consumption: the perception of baby boomers, generation $\mathrm{X}$ and $\mathrm{Y}$ in Brazil. Revista de Gestão Social e Ambiental, 11(3). https://doi. org/10.24857/rgsa.v11i3.1266

68. Shaban, Y., \& El-Bassiouny, N (2015). Sustainable consumption in Egypt: insights and implications. $21^{\text {st }}$ Annual Research Conference of the American University in Cairo (AUC). Cairo.

69. Shan, S., Peng, J., \& Wei, Y. (2021). Environmental Sustainability assessment 2.0: The value of social media data for determining the emotional responses of people to river pollution - A case study of Weibo (Chinese Twitter). SocioEconomic Planning Sciences, 75, 100868. http://doi.org/10.1016/j. seps. 2020.100868

70. Sharma, R., \& Jha, M. (2017). Values influencing sustainable consumption behaviour: Exploring the contextual relationship. Journal of Business Research, 76, 77-88. https://doi. org/10.1016/j.jbusres.2017.03.010

71. Sigala, M. (2014). Customer involvement in sustainable supply chain management A research framework and implications in tourism. Cornell Hospitality Quarterly, 55(1), 76-88. https://doi.org/10.1177\%2F1938965513504030

72. Spangenberg, J. H., \& Lorek, S. (2019). Sufficiency and consumer behaviour: From theory to policy.
Energy Policy, 129, 1070-1079. https://doi.org/10.1016/j.enpol.2019.03.013

73. Stern, P. (2000). New Environmental Theories: Toward a Coherent Theory of Environmentally Significant Behavior. Social Issues, 56(3), 407424. https://doi.org/10.1111/00224537.00175

74. Sun, B., \& Yang, X. (2019). Simulation of water resources carrying capacity in Xiong'an New Area based on system dynamics model. Water, 11(5), 1085. https:// doi.org/10.3390/w11051085

75. Sun, X., \& Guo, Y. (2018). The Ways of Educational Targeted Poverty Alleviation for the Poor in Rural Areas in Chongqing. Educational Sciences: Theory \& Practice, 18(6). http://dx.doi. org/10.12738/estp.2018.6.171

76. Tajfel, H. (1979). Individuals and groups in social psychology. British Journal of social and clinical psychology, 18(2), 183190. https://psycnet.apa.org/ doi/10.1111/j.2044-8260.1979. tb00324.x

77. Taufique, K. M. R., Vocino, A., \& Polonsky, M. J. (2017). The influence of eco-label knowledge and trust on pro-environmental consumer behaviour in an emerging market. Journal of Strategic Marketing, 25(7), 511529. https://doi.org/10.1080/09652 54X.2016.1240219

78. Tian, Q., Sato, M., Nakahara, H., Lee, S.-Y., Kang, J.H., \& Didham, R. J. (rev.ed.). (2011). The Role of Governments in Education for Sustainable Consumption: Strengthening Capacity For Effective Implementation In China, Japan, And Republic Of Korea (ISG Policy Report No. 2011-03). Institute for Global Environmental Strategies. Retrieved from https:// www.iges.or.jp/en/publication_ documents/pub/policyreport/ en/2465/iges-role_gov_edu_for_ sc_15dec2011.pdf

79. Viberg, O., Hatakka, M., Bälter, O., \& Mavroudi, A. (2018). The current landscape of learning analytics in higher education. Computers in Human Behavior, 89,
98-110. https://doi.org/10.1016/j. chb.2018.07.027

80. Vinz, D. (2009). Gender and sustainable consumption: A German environmental perspective. European Journal of Women's Studies, 16(2), 159-179. https://doi.org /10.1177\%2F1350506808101764

81. Wang, P., Liu, Q., \& Qi, Y. (2014). Factors influencing sustainable consumption behaviors: a survey of the rural residents in China. Journal of Cleaner Production, 63, 152-165. https://doi.org/10.1016/j. jclepro.2013.05.007

82. Wang, Y. (2017). Promoting sustainable consumption behaviors: The impacts of environmental attitudes and governance in a cross-national context. Environment and Behavior, 49(10), 1128-1155. https://doi.org/ 10.1177\%2F0013916516680264

83. Wang, Y., Xiang, D., Yang, Z., \& Ma, S. S. (2019). Unraveling customer sustainable consumption behaviors in sharing economy: A socio-economic approach based on social exchange theory. Journal of Cleaner Production, 208, 869-879. http://doi.org/10.1016/j. jclepro.2018.10.139

84. Wołek, M., Wolański, M., Bartłomiejczyk, M., Wyszomirski, O., Grzelec, K., \& Hebel, K. (2021). Ensuring sustainable development of urban public transport: A case study of the trolleybus system in Gdynia and Sopot (Poland). Journal of Cleaner Production, 279, 123807. https://doi.org/10.1016/j. jclepro.2020.123807

85. Wu, K., Wang, Y., Zhang, H., Liu, Y., \& Zhang, Y. (2021). On innovation capitalization: Empirical evidence from Guangzhou, China. Habitat International, 109, 102323. https://doi.org/10.1016/j.habitatint.2021.102323

86. Xia, T., \& Pei, J. (2021). The Impact of Digital Economy on Employment - Thinking Based on the Epidemic Situation in 2020. E3S Web of Conferences.

87. Yamoah, F. A., \& Acquaye, A. (2019). Unravelling the attitude- 
behaviour gap paradox for sustainable food consumption: Insight from the UK apple market. Journal of Cleaner Production, 217, 172-184. https://doi.org/10.1016/j. jclepro.2019.01.094

88. Yang, S., Li, L., \& Zhang, J. (2018). Understanding consumers' sustainable consumption intention at china's double- 11 online shopping festival: An extended theory of planned behavior model. Sustainability, 10(6), 1801. Retrieved from https://ideas. repec.org/a/gam/jsusta/v10y2018i6p1801-d149750.html

89. Zhang, H., \& Li, M. (2020). China's water diplomacy in the Mekong: a paradigm shift and the role of Yunnan provincial government. Water International,
45(4), 347-364. https://doi.org/10. 1080/02508060.2020.1762369

90. Zhang, W., Yu, Y., Zhou, X., Yang S., \& Li, C. (2018). Evaluating water consumption based on water hierarchy structure for sustainable development using grey relational analysis: case study in Chongqing, China. Sustainability, 10(5), 1538. http:// dx.doi.org/10.3390/su10051538 